\title{
VIETINIO POVEIKIO RANKUৃ KREMO SU MAŽALAPIŲ LIEPŲ ŽIEDŲ VANDENINE IŠTRAUKA MODELIAVIMAS IR KOKYBËS VERTINIMAS
}

\author{
Birutė Pockevičiūtè-Tarasovè, Regina Motienė \\ Kauno kolegijos Medicinos fakulteto Farmakotechnikos katedra
}

Raktažodžiai: rankų kremas, mažalapé liepa.

\section{Santrauka}

Rankų odą nuolat dirgina vidiniai ir išoriniai aplinkos veiksniai (cheminès medžiagos, UVA, UVB saulès spinduliai, temperatūros svyravimas, prausikliai, maiste esantys alergenai, hormonų kiekio pokyčiai brendimo, nėštumo ar biologinio senejjimo metu ir kt.). Išoriniai ir vidiniai veiksniai gali sutrikdyti epidermio apsauginę funkciją ir sukelti alergini atopinị dermatitą, egzemą, dilgèlinę ar kitas odos ligas, kurios pirmiausia pasireiškia pavienių ar kompleksinių nemalonių simptomų atsiradimu (niežuliu, paraudimu, patinimu, itrūkimu ar kt.). Nepageidaujami simptomai, pasireiškiantys rankų odoje, turi neigiamą poveiki asmens profesinei bei socialinei veiklai. Reguliarus rankų odos kremo naudojimas yra pripažinta veiksminga profilaktinè priemone, galinti apsaugoti nuo tolimesnių odos pažeidimų. Tyrimo objektas - du skirtingos sudeties laboratorijoje pagaminti rankų kremai. Tyrimo tikslas - sumodeliuoti vietinio poveikio rankų kremą su mažalapės liepos žiedų vandenine ištrauka ir ịvertinti kokybę. Puskiečių formų rankų kremo gamybos technologijos kūrimui ir igyvendinimui pasirinktos natūralios kilmès medžiagos: žalių kavos pupelių aliejus, mažalapių liepų žiedų vandeninè ištrauka, kakavos sviestas, emulsiklis „Olivem 1000“, eukalipto ir bergaminio citrinmedžio eteriniai aliejai. Anoniminès apklausos metu atskleista, kad 78,5 proc. tyrime dalyvavusių respondentų labiau patiko laboratorijoje sumodeliuotas rankų odos priežiūrai skirtas kremas, pagamintas su eukalipto eteriniu aliejumi. Pasak respondentu, ranku kremas pasižymejjo malonesniu kvapu. Remiantis gautais $\mathrm{pH}$ tyrimo rezultatais, galima teigti, kad bergaminio citrinmedžio eterinis aliejus kremui suteikia šiek tiek daugiau bazinių savybių, lyginant su kremu, kurio sudèties komponentu parinktas eterinis eukalipto aliejus.
pH reikšmių tyrimas atskleide, jog sumodeliuoti kremai tenkina žmogaus odos fiziologinius parametrus. Atlikus stabilumo tyrimus po 90 dienų, esant skirtingos temperatūros sąlygoms, nustatyta, kad nepakito kremų spalva, konsistencija bei kvapas.

\section{Ivadas}

Jau ilgą laiką žmonių piktnaudžiavimas vietinio poveikio priešuždegiminių, antimikrobinių cheminès sudèties preparatų vartojimu tapo itin didele problema. Mikroorganizmai mažiau atsparesni natūralios ir cheminès kilmès antimikrobinèms medžiagoms, kurios naudojamos vaistinių preparatụ gamyboje. Pasaulio sveikatos organizacija pripažista, kad reikia kurti inovatyvios sudeties vaistinius preparatus, kurie turètų stiprų antimikrobini poveikị. Moksliniai tyrimai orientuojasi ị naujesnių antimikrobinių medžiagų paiešką ir vaistinių preparatų sudèties technologinio proceso kūrimą. Vaistiniai augalai visada atrode patrauklus pasirinkimas inovatyvios sudeties preparato modeliavimui. Rankų kremų gamyboje vis dažniau naudojamos natūralios kilmès medžiagos, kurios pasižymi antioksidaciniu, antimikrobiniu, priešuždegiminiu poveikiu $[1,8]$.

Farmacijos pramoneje sukuriama vis daugiau vaistų, skirtų odos ligu gydymui, tačiau cheminiai vaistiniai preparatai nèra vienintelis būdas, siekiant pagerinti odos būklę ir ją apsaugoti nuo išorinių ir vidinių veiksnių (cheminių medžiagų, UVA, UVB saulès spindulių, temperatūros svyravimo, prausiklių, maiste esančių alergenų, hormonų kiekio pokyčių brendimo, nëštumo ar biologinio senejjimo metu ir kt.). Išoriniai ir vidiniai veiksniai gali sutrikdyti epidermio apsauginę funkciją ir paskatinti odos ligų vystymąsi. Keičiant odos fiziologinius parametrus saugiomis, efektyviomis dermatologinèmis natūralios kilmès priemonèmis, galima pasiekti odos gydomaji ar apsauginị poveikị. Optimalus epidermio drègmès kiekis gali mažèti, esant odos pažeidimų. Odos pH pusiausvyra yra silpnai rūgštinè ir siekia nuo 4,7 
iki 5,75. Oda nepajėgia neutralizuoti agresyvių, intensyvaus poveikio prausiklių, drèkinamujų priemonių su šarminiu $\mathrm{pH}$ ir kt., todèl pažeidžiama ląstelių struktūra, sutrinka viršutinio sluoksnio (epidermio) apsauginè funkcija. Naudojant lipofilinès-hidrofilinès kilmès kremus, suformuojama tam tikra odos apsauga, kuri apsaugo nuo dehidratacijos $[2,8]$.

Tendencingai didèja dermatologinių priemonių, kurių gamybai nenaudojami sintetinès kilmès produktai, paklausa. Natūralios kilmès preparatai sukelia mažiau alerginių susirgimų, apsaugo nuo mikroorganizmų patekimo ị organizmą. Moksliniais tyrimais įrodyta, kad natūralios kilmès vietinio poveikio drèkinamieji ar maitinamieji rankų kremai apsaugo odą nuo dehidratacijos, degeneracijos, UVA, UVB spindulių ir cheminių medžiagų poveikio bei sumažina vietinių kortikosteroidų poreikį. Vietinio poveikio rankų kremų naudojimas sumažina tikimybę susirgti egzema, alerginiu atopiniu kontaktiniu dermatitu, dilgèline ar kitomis odos ligomis [8].

Mažalape liepa - Tilia cordata Mill. Tai lapuotis medis, priklausantis dedešvinių (lot. Malvaceae) genties šeimai. Mažalapės liepos žiedynas turi nuo 3 iki 10 žiedų. Stipriai kvepiantys žiedai sudaryti iš gelsvai baltų žiedlapių ir taurèlapių [2]. Moksliniai tyrimai atskleidè, kad mažalapès liepos žiedų vandeniniai ekstraktai pasižymi stimuliuojančiu poveikiu (pagreitina limfocitų dauginimosi procesą). Be to, turi raminamaji poveiki [3-5]. Slopina gramteigiamas bakterijas (Staphylococcus aureus, Sarcina lutea ir Bacillus cereus, Listeria ivanovii) [4,6,7] ir patogenus (Salmonella Typhimurium, S. aureus ir Vibrio parahaemolyticus). İrodyta, kad mažalapès liepos etanoliniai, metanoliai ekstraktai, užpilai, nuovirai ir hidrolatai naikina grybelius, pasižymi antibakterinemis savybėmis ir yra veiksmingi prieš bakterijas Klebsiella pneumoniae, Morganella morganii ir B. cereus $[3,5]$.

Vietinio poveikio kremų sudèties kūrimui pasirinktos natūralios kilmès žaliavos. Mažalapès liepos žiedų cheminèje sudètyje gausu polifenolinių junginių. Mokslinių tyrimų metu identifikuoti didžiausi kiekiai šių cheminių junginių: flavonoidai (rutinas, hiperozidas, kvercetinas, izokvercetinas), fenolinès rūgštys (protokatecho rūgštis, galo rūgštis, kofeino rūgštis, kumaro rūgštis, chlorogeno rūgštis), eteriniai aliejai (farnezolis, farnezolio acetatas, geraniolis, eugenolis). Flavonoidai yra benzo- $\gamma$ pirano dariniai, kurių sudetyje yra fenolio ir pirano žiedai. Liepinių (lot. Tiliaceae) šeimos atstovų sudètyje daugiausia kvercetino ir kempferolio darinių. Kvercetino molekulè sudaryta iš penkių hidroksilo grupių, kurių buvimas ir nulemia junginių biologinị aktyvumą [1-3,5-7].

Tyrimo tikslas - sumodeliuoti vietinio poveikio ranku kremą su mažalapès liepos žiedų vandenine ištrauka ir įvertinti kokybę.

\section{Tyrimo objektas ir metodai}

Tyrimo objektas - laboratorijoje pagaminti dviejų skirtingų sudèčių kremai rankų odai.

Rankų kremų gamybai naudojama maceracijos būdu pagaminta mažalapès liepos žiedų vandeninè ištrauka, kuri pašildoma vandens vonioje. Riebalinė fazè, kurią sudaro žalių kavos pupelių aliejus, kakavos sviestas ir emulsiklis „Olivem 1000 “ išlydoma vandens vonioje temperatūros mažèjimo tvarka. Riebalinès ir vandeninès fazès pašildomos iki artimos temperatūros. Siekiant pagerinti emulsiklio ištirpimą ir pasiskirstymą, šildoma riebalinè fazè kartu su emulsikliu maišoma. Riebalinė fazè nedideliais kiekiais pilama ị vandeninę, intensyviai maišant. Maišant vykdomas emulsinimo procesas, todèl ši stadija labai svarbi, lemianti rankų kremo kokybę. Maišoma, kol kremas atvėsta. İ vientisą emulsinę masę įterpiamas praskiestas eterinis aliejus. Laboratorijoje pagaminti du vienodo pagrindo kremai, tačiau i juos įterpti skirtingi eteriniai aliejai (1:10 praskiesti eukalipto ir bergaminio citrinmedžio eteriniai aliejai). Eterinių aliejų skiedimui naudotas žaliujų pupelių eterinis aliejus.

Atliekant kremų juslinių savybių tyrimą, taikytas anoniminès anketinès apklausos metodas. Tyrimo metu apklausti Kauno miesto gyventojai, kurie analizavo laboratorijoje pagamintų lūpų balzamų juslines savybes: kvapą, spalvą bei konsistenciją. Juslinių savybių tyrime dalyvavo 220 respondentų, analizavusių laboratorijoje pagamintų vietinio poveikio rankų kremų kvapą, spalvą, konsistenciją. Tyrime dalyvavo 188 moterys ir 32 vyrai. Išskiriant amžiaus grupes, daugiausia tyrime dalyvavusių respondentų buvo 18-25 metų (47,50 proc.).

Rankų kremų pH reikšmės matuotos naudojant pH-metrą. 5 gramų rankų kremo mėginys šildomas vandens voneleje, ištirpinama $40 \mathrm{ml}$ išgrynintojo vandens. Gautas tirpalas filtruotas, o filtratui atvėsus pamatuota $\mathrm{pH}$ reikšmè. Atliekant $\mathrm{pH}$ tyrimą, į stiklinę, kurioje yra mėginys, įmerkiamas elektrodas ir užfiksuojama $\mathrm{pH}$ reikšmè. Po kiekvieno matavimo elektrodas nuplaunamas išgrynintuoju vandeniu. Kiekvienam mėginiui atlikti 3 matavimai ir išvesti aritmetiniai vidurkiai, standartinè paklaida.

Stabilumo tyrimais siekiama įvertinti, ar pagaminti rankų odai skirti kremai laikymo metu yra stabilūs. Pagaminti rankų kremai palikti stebèti 90 dienų. Tyrimas atliktas dalį kremų laikant $+5{ }^{\circ} \mathrm{C} \pm 1$ temperatūroje (šaldytuve), kitą dali - ịprastinèmis sąlygomis (kambario temperatūroje) nuo 18 iki $25^{\circ} \mathrm{C}$. Vertinami rankų kremų mėginių parametrai - tekstūra, kvapas bei spalva. Minèti parametrai vertinti kremų mėginius laikant skirtingomis sąlygomis: pagaminus, po 45 ir po 90 dienų.

Gauti duomenys apdoroti naudojant Microsoft $₫$ Office Excel 2010 programą. Rezultatu statistinis patikimumas ịvertintas naudojant IBM SPSS Statistics 25 programą. 


\section{Tyrimo rezultatai ir jų aptarimas}

Anoniminès apklausos metu atskleista, kuris iš kremu mėginių respondentams patiko labiau. 78,5 proc. tyrimo dalyvių išreiškè nuomonę, kad labiau patiko rankų odos priežiūrai skirtas kremas, pagamintas su eukalipto eteriniu aliejumi. Pasak respondentų, rankų kremas pasižymėjo malonesniu kvapu. 21,5 proc. apklausos dalyvių teigè, kad priimtinesnis rankų kremas, kurio sudetyje yra bergaminio citrinmedžio eterinio aliejaus.

Kremų sudèties komponentai įterpti lygiomis dalimis, naudojant tą pačią gamybos technologiją ir gaminant vienodomis sąlygomis, todèl kitiems anoniminèje apklausoje gautiems atsakymams skirtingas kremų kvapas įtakos neturejjo. Atliekant apklausą apie rankų kremų tekstūrą, konsistenciją ir spalvą, 45,5 proc. apklaustujų teigè, kad jiems patiko kremų konsistencija, mėginio turinys maloniai pasiskirsto ant odos, tačiau didesnè dalis tyrimo dalyvių mano, kad reikia koreguoti kremų konsistenciją. Tai būtų galima padaryti koreguojant kremų sudetinių dalių kiekius. 84,4 proc. respondentų patiko šviesiai gelsva kremų spalva. Spalvą suteike iš augalinės žaliavos ekstrahuotos pigmentinès medžiagos. 78,9 proc. apklaustujų teigè, kad kremų tekstūra yra priimtina, o 21,1 proc. - kad reikia koreguoti sudètinių dalių kiekį, nes kremai yra itin riebūs.

1 lentelè. Kremų pH reikšmių rezultatai

\begin{tabular}{|l|c|c|}
\hline \multirow{2}{*}{ pH } & \multicolumn{2}{|c|}{ Rankụ kremas su eteriniu aliejumi } \\
\cline { 2 - 3 } & eukalipto & $\begin{array}{c}\text { bergaminio citrin- } \\
\text { medžio }\end{array}$ \\
\hline pagaminus & $6,45 \pm 0,02$ & $6,55 \pm 0,03$ \\
\hline po 45 dienų & $6,48 \pm 0,04$ & $6,59 \pm 0,02$ \\
\hline po 90 dienų & $6,51 \pm 0,03$ & $6,65 \pm 0,04$ \\
\hline vidurkis & $6,48 \pm 0,03$ & $6,60 \pm 0,03$ \\
\hline
\end{tabular}

2 lentelè. Kremų stabilumo tyrimo rezultatai

\begin{tabular}{|l|c|c|c|c|}
\hline \multicolumn{4}{|c|}{ Kremas su eukalipto eteriniu aliejumi } \\
\hline \multirow{3}{*}{ Veiksniai } & \multicolumn{2}{|c|}{$\begin{array}{c}\mathbf{1} \pm \mathbf{1}^{0} \mathbf{C} \\
\text { temperatūra }\end{array}$} & \multicolumn{2}{c|}{$\begin{array}{c}\mathbf{1 8 - 2 5}{ }^{0} \mathbf{C} \\
\text { temperatūra }\end{array}$} \\
\cline { 2 - 5 } & $\begin{array}{c}\text { po } 45 \\
\text { dienų }\end{array}$ & $\begin{array}{c}\text { po } 90 \\
\text { dienų }\end{array}$ & $\begin{array}{c}\text { po } 45 \\
\text { dienų }\end{array}$ & $\begin{array}{c}\text { po } 90 \\
\text { dienų }\end{array}$ \\
\hline Kvapas & nepakito & nepakito & nepakito & nepakito \\
\hline Spalva & nepakito & nepakito & nepakito & nepakito \\
\hline Konsistencija & nepakito & nepakito & nepakito & nepakito \\
\hline Kremas su bergaminio citrinmedžio eteriniu aliejumi \\
\hline \multirow{5}{*}{ Veiksniai } & $5 \pm 1{ }^{0} \mathrm{C}$ temperatūra & $18-25{ }^{\circ} \mathrm{C}$ temperatūra \\
\cline { 2 - 5 } & $\begin{array}{c}\text { Po } 45 \\
\text { dienų }\end{array}$ & $\begin{array}{c}\text { Po } 90 \\
\text { dienų }\end{array}$ & Po 45 dienų & $\begin{array}{c}\text { Po } 90 \\
\text { dienų }\end{array}$ \\
\hline Kvapas & nepakito & nepakito & nepakito & nepakito \\
\hline Spalva & nepakito & nepakito & nepakito & nepakito \\
\hline Konsistencija & nepakito & nepakito & nepakito & nepakito \\
\hline
\end{tabular}

Pagaminus dviejų skirtingų sudèčių rankų kremus su mažalapès liepos vandenine ištrauka ir praskiestais eukalipto bei bergaminio citrinmedžio eteriniais aliejais, pamatuotos jų $\mathrm{pH}$ reikšmès pagaminus, po 45 ir 90 dienų. Atlikto $\mathrm{pH}$ reikšmių tyrimo rezultatai pateikiami 1 lentelèje.

Remiantis gautais $\mathrm{pH}$ tyrimo rezultatais galima teigti, kad praskiestas bergaminio citrinmedžio eterinis aliejus kremui suteikia šiek tiek daugiau bazinių savybių, lyginant su kremu, kurio sudèties komponentu parinktas praskiestas eterinis eukalipto aliejus. Lyginant abiejų kremų mėginių duomenis, gautas statistiškai reikšmingas skirtumas $(p<0,05)$. $p H$ reikšmių tyrimas atskleidè, jog sumodeliuoti kremai tenkina žmogaus odos fiziologinius parametrus.

Pagamintiems dviejų sudéčių kremams su mažalapès liepos vandenine ištrauka atliktas stabilumo tyrimas. Puskiečių formų stabilumas vertintas po pagaminimo praejjus 45 ir 90 dienų. Remiantis moksliniais šaltiniais, reikšminga stabilumo tyrimą atlikti $18-25{ }^{\circ} \mathrm{C}$ ir $5 \pm 1{ }^{\circ} \mathrm{C}$ temperatūroje. Tyrimo rezultatai pateikiami 2 lentelèje.

Atlikus stabilumo tyrimus, po 90 dienų nepastebèta 18$25{ }^{\circ} \mathrm{C}$ temperatūroje saugotų abiejų kremų spalvos, kvapo ir konsistencijos pokyčių. Vienodos pagrindinès sudèties kremų, laikytų $5 \pm 1{ }^{\circ} \mathrm{C}$ temperatūroje, reikšmingi veiksniai taip pat nepakito.

\section{Išvados}

1. Juslinių savybių tyrimo metu atskleista, kad didesnei respondentų daliai priimtinesnis rankų kremas, pagamintas su praskiestu eukalipto eteriniu aliejumi, kuris pasižymėjo maloniu kvapu, lengva konsistencija.

2. Atlikus kokybės tyrimus nustatyta, kad fiziologinius odos $\mathrm{pH}$ reikšmès parametrus tenkino abiejų sumodeliuotu sudèčių rankų kremai.

3. Remiantis moksline literatūra, atliktais tyrimais ir tinkamai parinkus hidrofilinès - lipofilinès fazių bei „Olivem 1000 “ emulsiklio santykius, sumodeliuoti ir pagaminti stabilios sudèties rankų kremai. Atsižvelgiant ị kremo sudètinių daliu fizikines ir chemines savybes, sukurta pusiau kietos aliejaus vandenyje $(\mathrm{a} / \mathrm{v})$ emulsinès sistemos technologija, naudojant 7 proc. nejoninès paviršinio aktyvumo medžiagos „Olivem 1000“.

\section{Literatūra}

1. Abdel Raoof GF, Mohammed HM. Cytotoxic effect and phytochemical study of petroleum ether extract of Tilia cordata Mill. Journal of Pharmaceutical Research 2019;4(4):13-15. https://doi.org/10.22270/ujpr.v4i4.292

2. Agner T, Jungersted JM, Coenraads PJ, Diepgen T. Comparison of four methods for assessment of severity of hand eczema. Journal of Contact Dermatitis 2013;69:107-111. 
https://doi.org/10.1111/cod.12039

3. Anesini C, Werner S, Borda E. Effect of Tilia cordata flower on lymphocyte proliferation: participation of peripheral type benzodiazepine binding sites. Journal of Fitoterapia 1999;70(4):361-67.

https://doi.org/10.1016/S0367-326X(99)00049-0

4. Barreiro Arcos ML, Cremaschi G, Werner S, Coussio J, Ferraro G, Anesini C. Tilia cordata Mill. Extracts and scopoletin (isolated compound): differential cell growth effects on lymphocytes. Phytotherapy Research 2006;20(1):34-40.

https://doi.org/10.1002/ptr.1798

5. Drzewiecka K, Piechalak A, Golinski P, Gasecka M, Magdziak Z, Szostek M, Budzynska S, Niedzielski P, Mleczek M. Differences of Acer platanoides L. and Tilia cordata Mill. Response patterns/survival strategies during cultivation in extremely polluted mining sludge e a pot trial. Journal of Chemosphare 2019;229:589-601.

https://doi.org/10.1016/j.chemosphere.2019.05.051

6. Özbucak T, Akcin OE, Ertuk O. The change in ecological, anatomical and antimicrobiological properties of the medicinal plant Tilia rubra dc. subsp. caucasica (rupr.) v. engler along an elevational gradient. Journal of Botany 2013;45(5):1735-1742.

7. Pietrzak W, Nowak R, Gawlik-Dziki U, Lemieszek M K, Rzeski W. LC-ESI-MS/MS identification of biologically active phenolic compounds in mistletoe berry extracts from different host trees. Journal of Molecules 2017;22:624.

https://doi.org/10.3390/molecules22040624

8. Ribet V, Mielewczyk E, Sirvent A, Georgescu V, Rossi AB. A novel dermo-cosmetic product containing thermal spring water, sucralfate, copper sulfate, and zinc sulfate in the management of hand eczema. Journal of Clinical, Cosmetic and Investigational Dermatology 2018;11:373-381.

https://doi.org/10.2147/CCID.S157849

MODELING AND QUALITY ASSESSMENT OF LOCAL EFFECT HAND CREAM WITH WATER EXTRACT OF LOWER LEAF

B. Pockevičiūtè-Tarasovè, R. Motienè

Keywords: hand cream, small-leaved linden.
Summary

Hand skin constantly suffers from irritating internal and external environmental factors (chemicals, UVA, UVB sunlight, temperature fluctuations, cleansers, allergens in food, changes in hormones during maturation, pregnancy, or biological aging, etc.). External and internal factors can disrupt the barrier function of the epidermis and lead to the development of allergic atopic dermatitis, eczema, urticaria or other skin diseases, which are primarily manifested by single or complex unpleasant symptoms (itching, redness, swelling, cracking, etc.). Undesirable symptoms occurring in the skin of the hands have a negative impact on a person's professional and social activities. Regular use of hand skin cream is recognized as an effective preventative measure that can protect against further skin damage. The objects of the research are two hand creams of different compositions made in the laboratory. The aim of the study was to model a topical hand cream with an aqueous extract of small-leaved lime blossoms and to evaluate the quality. Materials of natural origin have been selected for the development and implementation of semi-solid forms - hand cream production technology: green coffee bean oil, aqueous extract of small-leaved lime blossoms, cocoa butter, emulsifier "Olivem 1000", eucalyptus and bergamot lemon tree essential oils. An anonymous survey revealed that 78.50 percent respondents in the study preferred hand cream for hand skin care made with eucalyptus essential oil. According to the respondents, the hand cream had a more pleasant smell. Based on the results of the $\mathrm{pH}$ study, it can be stated that the essential oil of bergamot lemon tree gives the cream slightly more basic properties compared to the cream with the component of which is selected essential oil is from eucalyptus. A study of $\mathrm{pH}$ values revealed that the modeled creams meet the physiological parameters of human skin. Stability studies after 90 days at different temperature conditions revealed no change in the color, consistency and odor of the creams.

Correspondence to: birute.pockeviciute@go.kauko.lt

Gauta 2020-10-13 